Digital Press Social Sciences and Humanities

A Gentrification in Awiligar Dago as The Result of Tourism Industry: An Ethnographic Study

\title{
Aulia Mauludi
}

Proceeding of The 10th International Conference of Indigenous and Cultural Psychology 2019

Kwartarini Wahyu Yuniarti, Donald H. Saklofske, Rosnah Ismail, Saadi Lahlou (eds) 


\title{
A Gentrification in Awiligar Dago as The Result of Tourism Industry: An Ethnographic Study
}

\author{
Aulia Mauludi* \\ Murdoch University, Community Development, Perth, Australia \\ *e-mail: aulia_mauludi@yahoo.com
}

\begin{abstract}
Awiligar is a highland that is a part of Dago hills. The weather and view have fascinated people and corporations to develop its tourism industry. There are five types of Familiar visitors namely, people who (1) migrated to Awiligar from old villages at the top of the hill, (2) traveled from other regions in Bandung, (3) assimilated into the region (i.e., past convicts, colonialists, high-class members of the Indonesian society), and (4) corporations who built the tourist industries and infrastructures (e.g., hotels, outlets, restaurants). Those investments of time, energy, and effort into the tourism industry can be referred to as gentrification. Gentrification is a process by which marginal urban neighborhoods are rehabilitated and revitalized by incoming middle- and upper-class residents. There are two impacts of gentrification in Dago. The first being overcrowding and the second being the changes in the work division in modern industry, especially in terms of family structures.
\end{abstract}

\section{Keywords}

Awiligar, Dago, farmer, gentrification

\section{Introduction}

A community can be defined as a collective people that live in a functional relationship with one another within a specified geographical area with an awareness of their uniqueness and identity as a group (Schutte, 2018). In Indonesia, villagers can be defined as a community because they have similarities in geography and their relationship. Some of the Indonesian villages have traditional cultures that become their identities and their uniqueness.

Nowadays, traditional village communities have to face modern communities that try to take over their resources. This situation is stimulating a class conflict between the lower- and upper class through power distribution. Conflict theory states that tensions and conflicts arise when resources, status, and power are unevenly distributed between groups in society, and these conflicts become the engine for social change (Crossman, 2016).

In gentrification, the lower class has to be adaptable with upper-class culture. Gentrification is a process by which marginal urban neighborhoods are rehabilitated and revitalized by incoming middleand upper-class residents (Baione \& Brogna, 2018). The lower-class culture could not be adequately developed in comparing with upper-class culture. This is the problem of class existence. Marx in Communist Manifesto (1969) states that no one should have power over another that everyone should be equal. This situation in gentrification is leading to inequality, discrimination, and injustices (Galtung, 1996).

In this ethnography research, there are some points to explore, such as gentrification, geographical, share experience, and social points. The geographical point explains the reasons why Awiligar Dago attempted the upper class to modernize that area. The social reason describes the history and its changing from past to present. The share experience discusses the feeling of the people who lived in the gentrification area.

In Awiligar-Dago gentrification, the lower class lost their resources by selling their land to the upper class. The aim of this paper describes how the way the lower class lived in modern society historically when their culture clashed with modern culture in two aspects: geographically and socially. 


\section{Methods}

This is an ethnographic study, meaning that the research attempts to take a portrait of the people and their cultures. The methodology is for the descriptive study of the culture and the people. The parameters of this research are geographical, social, and share experiments (Beverley, Elizabeth, and Kate, 2009, 11). When using this approach, an ethnographer should observe, understand, and report, rather than judge behaviors, values, and interactions of the cultural groups studied (Fetterman, 2010).

In this case, the author will contrast the effect of gentrification in the social and geographical point of view from the people of Five Kampoengs that some of them moved to Hamlet 27. By using Ethnography, we could get a picture that was connected between the culture and demographic changes. The demographic data was taken from the descriptive statistic of government archives in Hamlet 27, especially the changing of population activity in the last ten years.

\section{Sample}

To understand the interaction among the groups in Five Kampoengs comparing the Hamlet 27, interviews were done with some significant people such as public figures (a 70 years old man who lived in Awiligar that knew the activities of Five Kampoengs and Hamlet 27), government officer (two persons who were a man and a woman who became officer more than 10 years and lived in Hamlet 27), business people (one operational hotel manager in Awiligar who became manager more than 2 years), and other significant members of society (two families consisted of father, mother, and children who lived around the Hamlet 27).

On the other hand, we took the data from 3 families in Hamlet 27 that lived in the Five Kampoengs before 1997 and moved to Hamlet 27 after 1997. Two of them were brothers who lived in the same area in Five Kampoengs and Hamlet 27. Another family was the oldest family in Hamlet 27 who moved to Hamlet 27. Those subjects represented the knowledge of activities in Five Kampoengs and Hamlet 27.

\section{Data Collection}

The data that was presented in this article has been collected through both interviews and observations. The author had made observations for almost 1,5 years since October 2017. All Hamlet 27 participants were the original members of the Five Kampoengs' population. The researcher interviewed through indepth interviews with the participant with open questions in their homes, in the public spaces, and in their working places. The guideline of the interview for the people who previously lived in five kampoengs was the comparison between the old place and the new place in the context of tradition, education, works, infrastructure, and social activities. For the observation, the researcher used participant observation to collect research data through observation where the researcher is involved in the daily activities of respondents (Bugin, 2007, p. 115). The aspects of this observation were the differences between infrastructures and cultures between the old place and the new place.

\section{Data Analysis}

The data analysis in this research used Spradley Ethnography research. Spradley (2007) had four stages for Ethnography analysis. First, the domain analysis was the analysis for depicting the general situation of object research. In this research, the author will describe two different times and areas between Hamlet 27 (new place for people who previously lived in Five Kampoengs) and Five Kampoengs. Second, the taxonomic analysis was the analysis based on domains that were classified by the author. Third, the component analysis was the explanation of the components that were connected by contrasting the elements. Forth, the cultural analysis was the analysis of the connection between the component and the general issue. 


\section{Geographical of Dago}

\subsection{History}

In 1873, the population of European increased around 500 people in Bandung (Hardjasaputra \& Sobana, 2002, p. 82). To manage the occupancy, the Dutch divided the entire population into three levels namely: 1) the group of Europeans; 2) the group of Indonesian people that were called pribumi and 3) the group of mixed Asian people, for example, the Arabians and Chinese communities. Three of them were spread in different places. The European people chose to live in Dago (the north of Bandung).

Dago was a famous tourist destination and was designed by the Dutch for European homestays. Dago was taken over by the Dutch from the local government because of plenty of European people living in the north of Bandung at that time (Lubis \& Nina, 2016, p. 163). The population of European people increased in Bandung in 1873 because some formal institutions had been moved to Bandung from Jakarta (Lubis \& Nina, 2016, p. 166). During that time, the Dutch planned to move Hindia Belanda capital from Batavia to Bandung. The main priority for housing in Bandung was in Dago. To do that, the colonial government developed Bandung to resemble the cities in Europe to make European people feel comfy (Hardjasaputra \& Sobana, 2002, p. 189).

\subsection{The Government}

Bandung became the third biggest city in Indonesia with a population of more than 138 people per Ha in 2002. The natural views and the attractive weather attracted people and developers to come and to explore Bandung. Based on UU Reformasi No. 22 1999, the local government was empowered by his rights to enhance its local potential resource (Dinas Informasi dan Komunikasi, 2002, p. 34). Unfortunately, this policy has stimulated the local government to exploit its Dago excessively without considering its capacity. The growth of Bandung's economy has stimulated so many social and environmental problems. Bappenas and UNDP $(2008$, p. 5) mentioned, "the movement rights from the central government to the local government about local exploration natural resource was corrupted and unfair in terms of distribution". The local government has increased the poverty gap index. The exploration in Dago that has developed the tourism and housing for the middle to high-class population had many impacts and mainly social issues, one of them was gentrification

\subsection{Dago and Its Luxurious Lands}

Politically, Dago was designed for European people by the Dutch government, because Dago had perfect natural resources, such as fertile land, warm weather, and clean air. They built houses, roads, plantations, and a variety of other amenities so that Dago became an exclusive area for housing because the blueprints of Bandung luxurious housing were settled in Dago by the Dutch government, especially Dago Pakar. The Dutch built so many exclusive houses in North Bandung for European people (Lubis \& Nina, 2016, p. 172).

Nowadays, the most popular area is Dago Resort. This place was developed from Five Kampoengs; Cikutra, Goleah, Cilimus, Cikuda, and Cicawana. The kampoengs were located on one of the tops of the Dago hills. There were some roads to access those kampoengs, the main road was Ir. H. Juanda and the secondary roads were Bojong Koneng and Awiligar. Bojong Koneng and Awiligar were built for connecting housing by the middle and lower class. When the war ended and the Dutch government moved from Bandung, the transfer of agriculture land was going to the local farmers. Suddenly, the local people in Five Kampoengs had a huge land to be planted and utilized. Unfortunately, the facilities in Dago that was built by the Dutch have attracted the corporates to develop houses and spaces for middle up society. It stimulated the corporates to evict the Five Kampoengs in Awiligar Dago. 


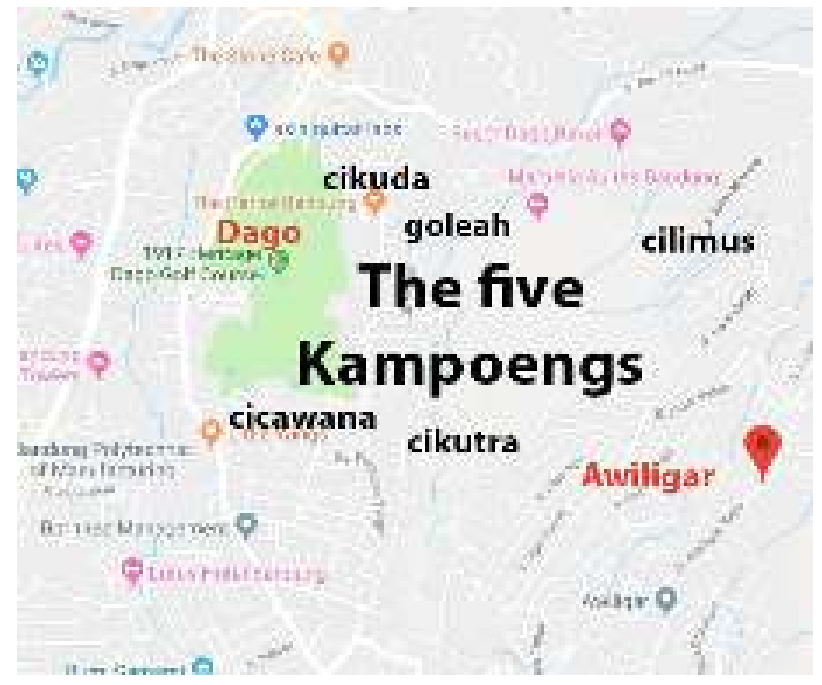

Fig. 1 Map of The Five Kampoengs in Awiligar Dago Awiligar: People from The Five Kampoengs moved, because land in Awiligar less price than land in Dago. Dago: The Ducth built infrastructure for European people

\subsection{Social Relation}

\subsubsection{The Five Kampoengs}

There is the same part of Awiligar and Dago that usually people name it as Awiligar Dago. Some of Awiligar's area is a part of Dago. Many years ago, Five Kampoengs existed not far away from Awiligar/Dago hills. Those kampoengs names were Cikuda, Cikutra, Goleah, Cilimus, and Cicawana (for the next text, it is called the Five Kampoengs). The houses in those kampoengs were traditional semipermanent houses that were mixed with wood and cement.

Those kampoengs were bought by Dago Resort from the 1990's until 1997. The last person who moved from those kampoengs was Yana. He moved from his village in 1997 for a reason. "Actually, I did not want to sell the house. I had two houses, one was in Goleah and another house was $1 \mathrm{~km}$ far away from Goleah. I had some brothers who lived in Goleah. At first, some of them started selling their houses to the Dago Resort company. When the Goleah had less population, because the Goleah's people had moved to the other kampoengs, I moved to my second house. I did not have friends who were staying in that village. For a couple of months, my house was not in good condition because no one looked after the house. I decided to sell it immediately."

In the colonial era, the kampoengs were dominated by agriculture lands. When the Dutch were defeated in Indonesia, those lands were transferred to the local people. Most of the people in Five Kampoengs were farmers after the independence of Indonesia and the rest of them became traders, laborers, and so on. Cikuda and Cilimus were the most popular agriculture areas among them all. The cassava, onions, and the other secondary crops became popular agricultural products from those areas. Like the other farmers in Indonesia, all of those kampoengs farmers bred livestock to add to their incomes. Cows, Goats, Chicken, and so on were the easiest to find in those kampoengs. All the certificates of those agricultural products were owned by local people. On the other hand, Goleah and Cikuda was the popular living area for the traders and laborers. Some people worked in agriculture, but the majority worked in the city as traders and laborers.

Those kampoengs were isolated from the other areas. There was no access and less technology in those areas. The people had to walk for $4 \mathrm{~km}$ if they wanted to access public transport to go to the city. Some of them were builders who worked far away from their villages. Mostly the village's people were lazy, but others were hard workers.

Yana was a prime example of a hard worker who worked almost every day from Goleah village to Jl. Moh. Toha, which was $17 \mathrm{~km}$ away from his village. Yana had to walk from Goleah to Jl. Suci and he had to catch public transport up from Jl. Suci to Jl. Moh Toha. Yana was a witness who was alive and shares his experiences with various authors. Every day, he had to go to his workplace in the morning and he had to go back in the evening around 5.00 p.m. There was a reason why Yana wanted to walk that far away to his 
workplace and kept staying in Goleah. Yana was one of the samples from Five Kampoengs people who wanted to explore his job. He did not want to be a farmer for his whole lifetime.

Living in those Five Kampoengs was quiet and relaxing. Some kampoengs were not too far away from the city that had smaller populations, the name is Cibeunying village. However, the people were interested more in staying at the kampoengs at the top of the hills than staying at Cibeunying village. Another reason why people wanted to stay on the top of the Awiligar Dago hills was that they could follow their ancestors who lived in those agricultural lands before. Yana said that Sundanese people who lived in the kampoengs were mostly lazy and uneducated. The people went to the fields and fed their livestock. After that, the villagers spent all their time in front of their houses to romanticize life and procrastinate.

There were no schools in those kampoengs. The nearest school was in Cigereleng and it was only one elementary school. It was hard to find people who stayed in those villages who had graduated from high school. Most of them lived a life of solitude as there was a small population and other villages were quite far away. There was only one recitation every Tuesday in those kampoengs.

Furthermore, the Sundanese people in those kampoengs were familiar with their lives as they had ideal environments with great scenery, suitable weather, and natural resources. European people stigmatized that the Sundanese people were indulged by their nature because Sundanese people obtained their needs easily from their natural resources. European people compare among the Sundanese people, American people, and Japanese people. Sundanese people slept too long and did not observe how other areas of society were progressing. Those terms that classified the Sundanese were lazy and uneducated (Ekadjati \& Edi, 2004, p. 65).

To evaluate the dignity of Sundanese people, Ekadjati and Edi (2004), said that the indicators of the human Sundanese index were education, profession, and their social role; how far the Sundanese people took a role to develop their community. In those kampoengs, the people were less educated as they either did not access to the educational facilities or they felt there was no need for this advancement in education to work with livestock and plantations. The people mainly did not work in formal professions that required specific knowledge. The people worked based on the same level every day and they did not enhance their knowledge. For Sundanese people, they have to avoid seven bad behaviors. The seven behaviors are madat (drugs), madon (prostitute), maen (gambling), minum (drunk), maling (theft), menyani (greedy), and mada (Killing). These values were more significant that knowledge. So that, the author assumed that the Sundanese index in the people of the Five Kampoengs was less. The shreds of evidence of this statement are:

Table 1 Sundanese

\begin{tabular}{|c|c|c|c|c|}
\hline Sundanese & Profession & Education & Social role & Index \\
\hline $\begin{array}{l}\text { Sundanese } \\
\text { standard }\end{array}$ & $\begin{array}{l}\text { There are many kinds of } \\
\text { work field and } \\
\text { increasing the } \\
\text { dedication of work }\end{array}$ & $\begin{array}{l}\text { There are many student } \\
\text { numbers and the grade of } \\
\text { education is high. }\end{array}$ & $\begin{array}{c}\text { There are many social } \\
\text { activities }\end{array}$ & \\
\hline $\begin{array}{c}\text { Five } \\
\text { Kampoengs }\end{array}$ & $\begin{array}{l}\text { The people mostly work } \\
\text { to be a farmer and local } \\
\text { trader without a } \\
\text { professional field }\end{array}$ & $\begin{array}{l}\text { There was only one } \\
\text { elementary school around the } \\
\text { villages. There are fewer } \\
\text { elementary students and } \\
\text { senior students. }\end{array}$ & $\begin{array}{l}\text { The village has fewer } \\
\text { activities after night and } \\
\text { there were fewer mosques } \\
\text { and public spaces in Five } \\
\text { Kampoengs. }\end{array}$ & LOW \\
\hline
\end{tabular}

\subsubsection{Land Selling and People Movement}

In 1990-1997, the kampoeng people started selling their lands to the Dago Resort. This was a moment when gentrification began in this area. In the cities of Indonesia, villages were one of the places that were renovated for modernism purposes; this was allowed by the government through private companies. The government that was supported by corporations; renovates and rebuilds new buildings on the kampoengs land's to modernize and to make the city more beautiful. They demolished some kampoengs in the slums and build modern infrastructures.

Phe and Wakely (2000) said that the role of social status in this process concerning housing location. The selection of residential was a way for people to express their power in the form of economic capital, social capital, and cultural capital. Dago resort built modern houses and its facilities that changed the concept of traditional Dago. Dago Resort was a company that aimed to provide housing and tourism facilities and also integrated all facilities in $320 \mathrm{Ha}$. The location for developing those were Five 
Kampoengs; Cikuda, Cikutra, Goleah, Cilimus, and Cicawana. In 1980, this place was taken over by Kabupaten Bandung from Kotamadya Bandung.

Dago Resort built Hotel Intercontinental Bandung Dago Pakar, Mountain View Golf Club, Kencana Resort Club, Marbella Suites Bandung, Commercial Area, and Bina Bangsa School (Resort Dago Pakar, 1990). On the other hand, they built luxury houses for successful businessmen and the plutocrats for them to buy all lands in those areas gradually. This process needed seven years to complete all the purchasing; because the people had a large amount of land, some people earned around 500-750 million. After the kampoengs' people moved from their lands, those kampoengs were invaded by rich people and plutocrats. Those villages were surrounded by some big hotels, for example, Intercontinental, Clove Garden, Swiss Bell, Marbella Suit, and so on. In the middle of those kampoengs a giant golf park was added for the rich men, they could buy houses and get all the facilities of natural tourism in Dago Pakar.

\subsubsection{The Kampoengs' People}

When the Kampoengs' people earned their money from land trading, some of them moved to the small cities near Bandung, such as Indramayu, Garut, Tasik, etc but, the majority of the population of those kampoengs moved to Awiligar, because their kampoengs were accessible from Awiligar. In Awiligar, they lived in Cibeunying kampoengs that caused the Cibeunying kampoengs to become overpopulated. Jono and Yana were samples of people who moved from old kampoengs to the new kampoengs. Yana brought four core families to move to Cibeunying village.

The kampoeng people bought the land in Cibeunying kampoengs from Soejono, the biggest landowner in Awiligar. Soejono lives in the city, but he has huge land in Awiligar. The other persons who have broad lands in Awiligar came from Sumatera, they worked as loan sharks. They took over the land from the people who owed them and were unable to pay the loan back. They took some people from Five Kampoengs to handle their land.

Nowadays, there are three classifications of the people who live in Awilgar. Firstly, the people who moved from the Five Kampoengs to Cibeunying kampoengs. Hamlet 27s have 776 persons that lived together in that region. A total of $80 \%$ of that population was the population that came from Goleah village. Some of them were the families that built their houses next to each other. Secondly, the people who were brought as recidivists to be assimilated in the hills. Tarigan was a school owner in Indonesia. His land was used to assimilated recidivists, and one of the recidivists was a Sumatran traditional restaurant owner in Awiligar. This population was lesser than the other population. Thirdly, people who migrated from the other regions. One of the reasons why people moved to Awiligar is the price. In 1990, in the other highlands, the cheapest option people were able to pay 500 thousand per 14 meters ${ }^{2}$, but in Awiligar they just paid 250 thousand per 14 meter $^{2}$. This is a considerably low price for land in the Bandung area. Fourthly, people who worked in the tourism area and luxurious houses. The manager and the employees of the hotel, some of them stayed in the building temporarily or permanently. The permanent employees were around 90 persons and the casual employees were around 10-40 people, depending on their situations. On the other hand, the customers and the apartment owners were counted as permanent and temporary residents as well. Fifthly, the corporate owners who stay temporarily or permanently. 


\subsubsection{Demography}

Table 2 Demography of hamlet 27 population

\begin{tabular}{lc}
\hline \multicolumn{1}{c}{ HAMLET 27 } & $N$ \\
\hline Sex & \\
Men & 396 \\
Women & 363 \\
\multicolumn{1}{c}{ OCCUPATION } & \\
Builder & \\
Farmer & \\
Casual & \\
Pension & 112 \\
Army & 4 \\
Permanent builder & 1 \\
Businessman & 18 \\
\multicolumn{1}{c}{ GRADUATED } & 8 \\
Kindergarten & 18 \\
Elementary School & 72 \\
Junior High School & 67 \\
Senior High School & 12 \\
Diploma & 38 \\
First Graduate & 1 \\
Postgraduate & 1 \\
Elementary School & \\
Men & \\
Women & \\
Junior High School & \\
Men & \\
Women & \\
Senior High School & \\
Men & \\
Women \\
Bachelor \\
Women
\end{tabular}

Note: Data was taken from the government officer of Hamlet 27

Hamlet 27 permanent population was composed of 396 men and 363 women. That number did not include the hotel employees and their guests. The most popular job in that area was the casual workers. There were 112 casual workers in the Hamlet 27 that worked as builders, farmers, etc. When in the Five Kampoengs, the most popular job was farmer, because most people had land that was used for planting onions, cassavas, etc. When the people of the Five Kampoengs moved to Hamlet 27, the people did not have spacious land because the land was limited for housing and public facilities. In Hamlet 27, the farmer rented lands to the landlords for planting. This was difficult because the farmers needed more money to plant in Hamlet 27 than in Five Kampoengs, rented and planted.

\subsubsection{Works}

In Five Kampoengs, people worked from the morning until the middle of the day. After that, they fed the livestock and came back to the fields in the evening. The agriculture was not far away from their homes, so the wives helped their men to plant in the plantation. The wives did not bring the harvest to the market and negotiated with the agent, because the market was far away from their homes. The farmer thought that women had to stay closer to their homes than a man because the wives had to look after 
their children and to do homework. Alma (2008) notes several constraints and obstacles faced by female 1) Traditional home activities; 2) Social and cultural factors, expect that women should play a traditional role as caregiver for the family. Women have been heavily influenced by the traditional structures that dictated sex roles, family structures, work, and appropriate characteristics for women. Women were defined by her social structure, although for their leisure time (Henderson, Hodges, \& Kivel, 2002, pp. 253-271).

In Hamlet 27, the plantation was far away from their homes, because there was no plantation in Hamlet 27. Thus, the husbands worked in the plantation and the wives opened small stores in their house (warung) to support their family's economies in different ways. The main job for a wife was nurturing and supporting her husband to earn some money through warung.

The other jobs in Hamlet 27 are 4 (pensions), 1 (army), 18 (permanent builders), and 8 (businessman). Based on that data, the casual workers made up 70\% and it is the biggest job in Hamlet 27. 30 people worked in Clove Garden hotel and only around 3 persons worked as a housemaid in Dago Resort. When the Dago Resort bought the kampoengs, the Dago resort promised to absorb the local people to be employees. Almost all the Five Kampoengs people were interviewed to look for what kind of skill of The Five Kampoengs people had. The problem came up when the gap of job requirements and the Five Kampoengs skill was quite huge.

The Clove Garden fulfilled its promise to absorb 30\% of people who worked in the hotel. Some of Hamlet 27 people worked as security or cleaners. On the other hand, the Dago Resort was hard to absorb employee from Hamlet 27, because the requirement and the people thought that they were not suited to work in assistant houses in Dago Resort. Some people said that they don't know the culture of upper-class people.

\subsubsection{Education}
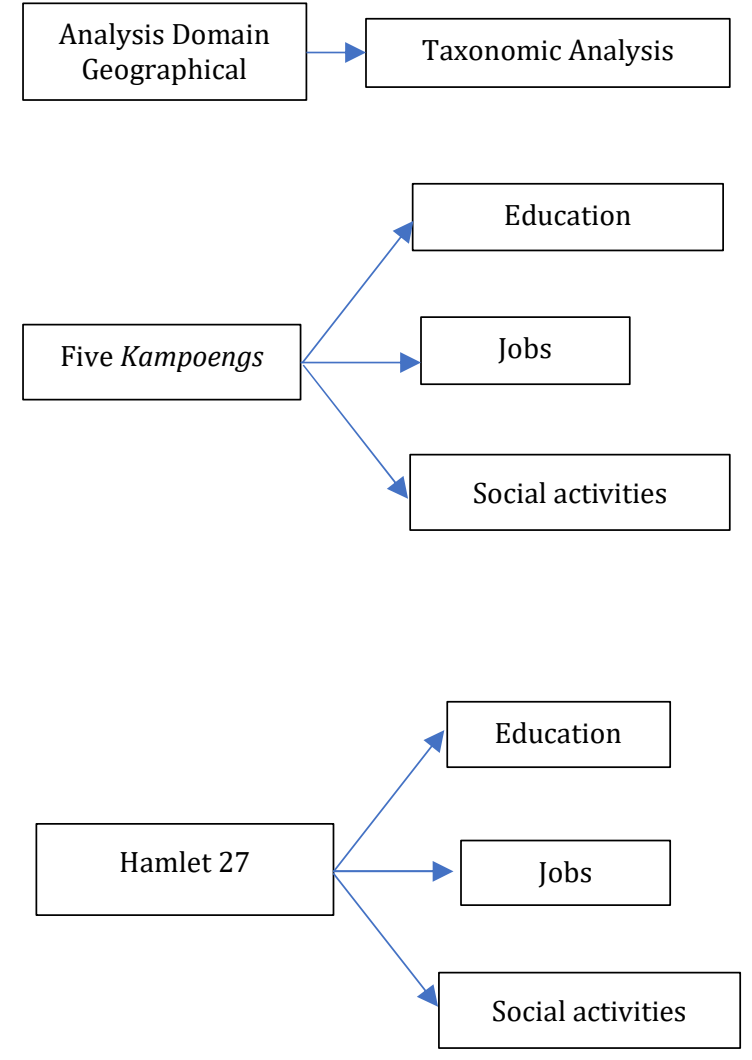

Component Analysis

Lower than Hamlet 27 because there was no school in Five Kampoengs. Their way of life did not need special education. They were farmers and builders.

Less Variant than Hamlet 27. Majority people in Five Kampoengs worked as bulder and farmer. They have plenty land to be planted. Those land were not far away from their house, in order that the wives can help the husband and did the domestic jobs.

Less activities than Hamlet 27. The Five Kampoengs were far away from the main road. The infrastructure had not been built to access the Five Kampoengs, such as road, light, etc.

They were more school comparing the Five Kampoengs. On the other hand, the student amount increased for some reasons e.g. the modernism that motivates the Hamlet 27 people to study for their better future.

More variant than Five Kampoengs. There were new kind of job in Hamlet 27, because there were no free land and reachable land to be planted in Hamlet 27.

People worked, played, and acted from the dawn until late night. The infrastructure in this Hamlet was much better. The children could have activities in mosque till the dark, the people can gather to the public space easily, because the light and the road was getting better. The shops could open until 9 pm.

Fig. 2 Comparison Hamlet 27 and Five Kampoengs 
The education graduation of Hamlet 27 people was kindergarten 18 persons, Elementary school 72 persons, Junior High School 67, Senior High School 12, diploma 3 persons, first graduate 1 person, and postgraduate 1 person. Based on these data, everyone assumed that education was not the priority of Hamlet 27 people who moved from the Five Kampoengs. Mostly they were graduated from Elementary School or Junior High School. This is not too different in comparing the Five Kampoengs based on information of the Five Kampoengs people. The author cannot get the data of five villages, because the head Kampoengs has passed away and the office has gone.

Nowadays, the amount of current students has increased in comparison to old people. On the other hand, the empowering women raised in comparison to the traditional era. Almost all women aged school take study formally in school. The amount of student, for now, are elementary school 90 students (48 m42 f), Junior High School 65 students (38 m-27 f), Senior High School 47 students (23 m-25 f), post Senior High School 94 (48 m-46 f). Based on the record of school age in Hamlet 27, the author assumed all the people who are 7-24 old years were students.

Dayat was one of the many Goleah original members who earned money from land trading. He said that Goleah people spent their money to buy a new house and vehicle. Some people bought a vehicle to support their work. He worries about his next life in the new area. The people who came from Goleah usually spent their money on their children's education. The next generation of Hamlet 27 was promising to be absorbed in the tourism industry. The school was the bridge to reduce the gap in culture.

\subsubsection{Share Experience}

There were many experiences for the people who lived in Five Kampoengs before. Mrs. Fitri lived in Goleah when she was a young girl. There were some childhood memories that she remembered about her home villages. The villages were isolated from the main road. When the dark came, no little girls were brave to pass from the main road to the village's road. The people believed that the road was haunted in the dark, therefore, the activities in the Five Kampoengs ended at $6 \mathrm{pm}$.

In the new Mrs. Fitri village, the people work until late at night. The main road was not far away from her new village. On the other hand, the walking path was better than the old road. The lighting was provided by the local government because the village was not far away from the city. The mosque can be accessed by the people from the dawn till the dark. "It is better now because we can socialize more than before. I am not worried to let my children go in the night," Mrs. Fitri said.

The people enjoyed their leisure time in the afternoon in the Five Kampoengs. They found many lands that were not far from their home that can be planted with many plantations. It helped them to frequently go home after breaking in their planting hours because they worked for himself informally. In the modern world, they cannot go home in working hours frequently. For example, Mr. Dadang is working as a security in the hotel. He must work from the morning until the night to save and to park the guest's cars. He could not go home in the afternoon when his working hours have not finished yet. The working time is different in comparison with the old kampoengs and the new kampoengs because for now the working hours are defined by modernism.

"We want to come home frequently because the job is boring.", Mr. Dadang said. Some of Mr. Dadang friends said similar things. They feel that modernism was not suitable for their lifestyle. The most important thing from modernization happened to the children of the village. They were happy with their new kampoengs. They studied in school that was not far away from their new kampoengs. Even though their parents worked full time, they can play with their peers in the afternoon, because their house was closed with the other houses. In Five Kampoengs, they must walk away to meet their friends.

\section{Discussion}

There were many differences between people who lived in five kampoengs and Hamlet 27. Education, job, and social activities were aspects of those differences. On the other hand, the infrastructures in those areas were differences as well. Those supported the people to changed and explored their lifestyles.

The differences in education in five kampoengs and Hamlet 26 were influenced by two factors, the infrastructure, and the culture. In Hamlet 27, there were more schools for elementary schools, junior high schools, and senior high schools than five kampoengs. Moreover, the facilities to reach the schools had been built by the government, for example, the main road and transportation were more accessible in Hamlet 27. 
The education cultures had changed since the people moved to Hamlet 27. Various kinds of jobs needed more options for education to enhance their skill. The changes in their work from traditional skills to modern skills stimulated them to educate their next generation through school. People realized that education was very important to bring them to modern life.

The process of gentrification usually pushed people to take study higher than before. With the increase of middle- and upper-class individuals in a gentrified neighborhood, these families tend to be more involved in the education of their children and match that with more demands on the local school system (Hankins, 2007).

The situation in the new place had driven people to look for many options for jobs. For example, the situation of lack of farmland stimulated people to work in factories or shops. The position of the Hamlet 27 that was closer to the main road than five kampoengs, attracted people to explore more jobs than in five kampoeng so that, the option of their job was getting much.

The benefit of moving from five kampoengs to the Hamlet 27 was about money. The people sold their house more expensive than the normal price because the Dago Resort Co. paid them more. Gentrification is beneficial to those who are homeowners because they can sell their houses for a higher price than what they bought it for (Atkinson, 2002).

The money was spent to buy facilities to work and to study. Yana stated that many people bought motorcycles and houses to spend their money from house selling. On the other hand, people pay more for education to educate their children. With the increase of middle- and upper-class individuals in a gentrified neighborhood, these families tend to be more involved in the education of their children and match that with more demands on the local school system (Hankins, 2007).

\section{Conclusion}

In 1990, the people of Five Kampoengs mostly were farmers. When the modernism came to their kampoengs, the people had to move to the next kampoeng, because all their kampoengs was sold to the developer (Dago Resort Company). The developer developed houses, hotels, and other modern facilities. The modernism that worked around had to be adapted by the Five Kampoengs people through education and attitude.

Geographically, the Dago was designed by the Dutch to be an exclusive place. When the Dutch moved from Indonesia, the lower class community replaced that area. When the Indonesian upper class bought the Dago area, the people who lived around Dago had to face the modernism. Five Kampoengs in Dago had been rebuilt to be the luxury place for the Indonesian upper class and the lower-class people lived around that.

Socially, people who lived in Five Kampoengs keep their traditional culture, even though they did not live in an authentic Sundanese way, they were lazy, uneducated, etc. On the other hand, they changed their work from farmers dominated to labor and businessman dominated after they moved. Thus, the family structure had been changed as well, for example, a wife cannot help her husband in his working place, because the working places are far away from home. The wife can work around the house only because they had to do the domestic works in the house. On the other hand, the people from old kampoengs got more variant in jobs. For education, there was more school in Hamlet 27 than the Five Kampoengs caused the people to access education easily. It is a good indicator to raise the education index for accepting modernism.

Shared experience, the people had a different feeling in new kampoengs. Some of them were happy because the modernism had enhanced the facilities in their new kampoeng. Their activities can be done in the morning until late at night because the lighting and the road were proper than in Five Kampoengs. On the other hand, some of them felt that modernism activities were boring because it was too strict, monotonous, and rigid. "I left the hotel because I just took stairs to take dirty clothes every day," Mrs. Fitri said.

To sum up, the lower class people changed their social lives and their environment to be adaptable to modern life. Some of them felt happy and welcomed to modernism, some of them had to be more bored with modernism. In the future, they will be part of modernism culture and to support upper-class people. This indication came from the rising of students, a variant of jobs, and activities hours. To reduce the conflict, the lower class tried to be part of modern culture. 


\section{Reference}

Alma, B. (2008). Kewirausahaan: Untuk Mahasiswa dan Umum. (Entrepreneurship for Students and Public). Bandung: Alfabeta.

Atkinson, R. (2002). Does Gentrification Help or Harm Urban Neighborhoods? An Assessment of The Evidence-Base in The Context of The New Urban Agenda. Glasgow: ESRC Center for Neighborhood Research.

Baione, \& Brogna, A. (2018). Gentrification: A Tangled Web of Cause \& Effect.

Bappenas, \& UNDP. (2008). Study Dampak Pemekaran Daerah, 2001-2007.

Bugin, B. (2007). Penelitian Kualitatif. Jakarta: Prenada Media Group.

Crossman, A. (2016). Conflict Theory: A Brief Overview. Retrieved November 10, 2019, from http://sociology.about.com/od/Sociological-Theory/a/Conflict-Theory.html

Dinas Informasi dan Komunikasi. (2002). Selayang Pandang Kota Bandung. Pemerintah Kota Bandung.

Ekadjati, S., \& Edi. (2004). Kebangkitan Kembali Orang Sunda: Kasus Paguyuban Pasundan 1913-1918. Bandung: Kiblat Buku Utama.

Fetterman, D. M. (2010). Ethnography: Step-by Step Guide (3rd Ed.). Los Angeles: Sage.

Galtung, J. (1996). Peace By Peaceful Means: Peace and Conflict, Development and Civilization. US: Sage Publications.

Hankins, K. B. (2007). The Final Frontier: Charter Schools as New Community Institution of Gentrification. Urban Geography, 28(2), 113-128. https://doi.org/10.2747/0272-3638.28.2.113

Hardjasaputra, A., \& Sobana. (2002). Sejarah Kota Bandung 1810-1945. Pemerintah Kota Bandung.

Henderson, K. A., Hodges, S., \& Kivel, B. D. (2002). Context and dialogue in research on women and leisure. Journal of Leisure Research, 34(3), 253-271.

Lubis, H., \& Nina. (2016). Sejarah Kota Bandung. Pemerintah Kota Bandung.

Marx, K., \& Engels, F. (1969). The Communist Manifesto, Vol. One. Moscow: Progress Publishers.

Phe, H. H., \& Wakely, P. (2000). Status, Quality and The Other Trade-Off: Towards A New Theory of Urban Residential Location. Urban Studies, 37(1), 7-35.

Resort Dago Pakar. (1990). Sejarah Resort Dago Pakar. Retrieved November 10, 2019, from https://www.resordagopakar.com/about

Schutte, D. W. (2018). The Basic Need Theory for Community Development. https://doi.org/10.13140/RG.2.2.11882.98243

Spradley, J. (2007). Metode Etnografi (2nd Ed.). Yogyakarta: Tiara Wacana. 